\title{
Evaluation of the Effect of the Sesame Paste (Sesamum indicum) as Partial Fat Substitute in Hamburger Meat
}

\author{
Piedad M. Montero Castillo ${ }^{\# 1}$, Erica P. Torres-Julio ${ }^{* 2}$, Dayana P. Pérez-Rodríguez ${ }^{\# 3}$ \\ Faculty of Engineering, Food Engineering program, Research Group NUSCA, University of Cartagena \\ Av. El Consulado, St. 30 No. 48-152. Cartagena de Indias, Colombia. \\ 1'pmargaritamontero@hotmail.com, ${ }^{2}$ etorres@unicartagena.edu.co, ${ }^{3}$ dayanappr@gmail.com.
}

\begin{abstract}
Meat products are an important component in a healthy and balanced diet, as a result of their nutritional richness, especially in proteins of high biological value and micronutrients (iron, selenium, zinc and vitamin B12).However, many of the processed meat products contain high amounts of fat, salt, saturated fatty acids and cholesterol that potentially harm the consumer, which is why the aim of this research was to evaluate the effect of adding different levels of sesame paste as a partial fat substitute in hamburger meat.Three treatments were formulated with the addition of sesame paste T1 (5\%), T2 $(10 \%)$, T3 (25\%) and a control T4 without the addition of paste. Bromatological properties, fatty acid profile and cholesterol were evaluated.Texture profile, physical properties, microbiological and sensory analysis and data processing were also performed in the SPSS program, version13.The results showed better performance in $\mathrm{T} 2$ treatment with a higher percentage of protein and a lower fat content of $18.07 \%$ and $26.56 \%$ respectively. The use of sesame paste was significant in reducing cholesterol by $58.65 \%$, and also generated a beneficial effect on the saturated fraction of the product.
\end{abstract}

Keyword - Texture Profile, Physical Properties, Microbiological and Sensory Analysis.

\section{INTRODUCTION}

Sesame paste, or tahine, is produced from husked sesame seeds. This product is of high nutritional value because it is rich in lipids ( 57 to $67 \%$ by weight); it contains unsaturated fatty acids omega 6 and omega 9 (oleic and linoleic), which increase the liver synthesis of good cholesterol or HDL, proteins ( 23 to $27 \%$ by weight);

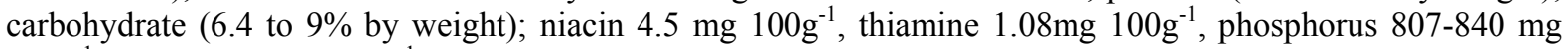
$100 \mathrm{~g}^{-1}$ and iron $9 \mathrm{mg}^{100 \mathrm{~g}^{-1}}[1]$. By-products obtained from sesame seed processing can be considered an excellent source of dietary fibre and can be used as a functional ingredient [2]. Sesame oil or sesame paste is an ideal fat substitute for meat products, as it contains a high content of polyunsaturated fats and has a rich and unpleasant taste [3]. It is known to reduce cholesterol due to the high content of polyunsaturated fat in the oil, contains lignans, sesamine, sesamoline and sesamol which have antioxidant activity and is very stable against oxidation deterioration [4].

Fat is one of the main constituents of food, it influences the functional and sensory characteristics of meat derivatives, due in large part to its contribution to the taste, texture, juiciness, general feeling of lubricity of the product, among others.However, in recent years due to the growing consumer demand for healthy products, the fat content of meat formulations has been decreasing in order to develop meat products with an added nutritional value[5], [6], because fat, particularly animal fat, often contains high levels of saturated fatty acids and cholesterol, which have been associated with the development of diseases such as obesity, hypertension, cardiovascular and coronary heart disease [7].A wide variety of methods have been proposed to reduce fat content in meat without substantially affecting texture: the use of low-fat raw materials, water addition, fat substitutes and fat mimetics[8].Fat replacers can be classified into mimic greases, grease spreaders and fat substitutes. These replacers provide characteristics such as viscosity, creaminess, palatability, among others, with a low calorie intake that varies between $0-5 \mathrm{kcal} / \mathrm{g}[8]$.

Meat products are an important component of a healthy and balanced diet, as a result of their nutritional richness. Especially rich in proteins of high biological value and micronutrients such as iron, selenium, zinc and vitamin B12.However, many processed meat products also contain high amounts of fat, salt, saturated fatty acids and cholesterol that are potentially harmful to the consumer.On the one hand fat provides a source of flavour substances, forming directly or indirectly aldehydes, ketones, alcohols and phenols[9], however, the fat functions in the emulsion system improve product quality by stabilizing the meat emulsion, reducing cooking loss, improving water holding capacity and providing juiciness and an adequate level of hardness.

Therefore, the meat industry is facing a new challenge how to find a substitute for fat replacement to produce a healthy, low-fat meat product with adequate texture properties and, above all, overall stability[10].The objective of this research was to evaluate the effect of adding different levels of sesame paste as a partial fat substitute in hamburger meat. 


\section{MATERIALS AND METHODS}

\section{A. Formulation of hamburger}

Beef and pork fat were purchased from chain stores and kept refrigerated until they were used. The ingredients and seasonings were purchased from a company that supplies inputs to the meat industry.Sesame paste was produced following the methodology by Julio et al.[11]. For the preparation of the hamburger, the meat and fat were mixed and kneaded together with the ice, sesame paste and binder were homogenized during 3-4 min in a Mainca ${ }^{\circledR}$ cutter for food processing model CM14 controlling the temperature of $10 \pm 2{ }^{\circ} \mathrm{C}$ to avoid denaturing the proteins, then the remaining ingredients and ice were added (Table 1).Instantly molds of $18 \mathrm{~cm}$ diameter by $1.2 \mathrm{~cm}$ high were made with a weight of $120 \mathrm{~g}$.Afterwards, they were packed in zip lock plastic bags to avoid humidity and drying, finally they were frozen at $18{ }^{\circ} \mathrm{C}$ for $24 \mathrm{~h}$ until the other analyses were carried out.

\begin{tabular}{|c|c|c|c|c|}
\hline Raw Material & \multicolumn{4}{|c|}{ Treatments } \\
\hline \multirow{2}{*}{ Beef } & $\mathrm{T} 1$ & $\mathrm{~T} 2$ & $\mathrm{~T} 3$ & $\mathrm{~T} 4$ (control) \\
\cline { 2 - 5 } & $70 \%$ & $70 \%$ & $70 \%$ & $70 \%$ \\
\hline Pork fat (\%) & 15 & 10 & 5 & $20 \%$ \\
\hline Sesame paste (\%) & 5 & 10 & 15 & $0 \%$ \\
\hline Ice (\%) & 10 & 10 & 10 & $10 \%$ \\
\hline Binder (\%) & 5 & 5 & 5 & $5 \%$ \\
\hline Nitrate salt (ppm/kg) & 200 & 200 & 200 & 200 \\
\hline Polyphosphate (\%) & 0.5 & $0.5 \%$ & $0.5 \%$ & $0.5 \%$ \\
\hline Salt (\%) & $2 \%$ & $2 \%$ & $2 \%$ & $2 \%$ \\
\hline
\end{tabular}

\section{B. Analytical determinations}

The determination of moisture, protein, fat and ash was carried out according to Colombian technical standards. We evaluated the bromatological properties of NTC 1663, NTC 1556 moisture, NTC 1662 protein, NTC 1678 fat and ashes [12]; the fatty acid and cholesterol profile according to the AOAC method[13].

\section{Texture profile}

The texture profile was determined with a TAXT2i Texture Analyzer (Stable Microsystems, Godalming, UK), with a $5 \mathrm{~kg}$ load cell, and the software provided by the manufacturer (texture experd exceed, version 2.63) in order to simulate human chewing.For this purpose, meat slices of approximately $2.5 \mathrm{~cm}$ thick were cut and allowed to stand for one hour at room temperature inside a polyethylene bag to avoid moisture loss. The treatments were subjected to a compression of $70 \%$ and a speed of $60 \mathrm{~mm} \mathrm{sec}^{-1}$, obtaining the force/time curve to determine the parameters such as hardness, adhesiveness, elasticity and fracturability.

D. Physical properties

The physical characteristics studied were cooking performance (RC), grease retention (RG) and moisture retention (RH) after cooking. These tests were performed on a random number of three samples per lot. Each sample was weighed before and after cooking, using the following equations:

1) Cooking yield: It was determined by measuring the weight of three hamburgers for each treatment and calculating the weight differences for hamburgers before and after cooking, according to Göket al.,[14] as follows, equation 1 :

$\% \mathrm{RC}=\frac{\text { cooked weight }}{\text { raw weight }} \times 100$

2) Moisture and fat retention: Fat and moisture retention values represent the amount of moisture and fat retained in the cooked product per $100 \mathrm{~g}$ of raw sample. These values were calculated according to equation 2 and $3[15],[16]$.

$\% \mathrm{RH}=\frac{\% \text { yield } \times \% \text { cooked hamburguers moisture }}{100}$
$\% \mathrm{RG}=\frac{\text { cooked weight } \times \% \text { cooked hamburguer fat }}{\text { gross weight } \times \% \text { raw hamburguer fat }} \times 100$

\section{E. Cooking procedure}

The meat burgers were cooked using an electric grill (Arçelik Micro Grill, Turkey) at $220^{\circ} \mathrm{C}$ (distance between heat source and samples was $4 \mathrm{~cm}$ ) for $8 \min (4 \mathrm{~min}$ for each side of meat burgers) (samples of meat burgers were internally cooked at $80^{\circ} \mathrm{C}$ ). The weight and diameter of meat burgers per batch were measured at room temperature before and after cooking to calculate cooking loss and diameter reduction. 


\section{F. Microbiological analysis}

The microbiological analysis was carried out in accordance with the procedure established by Colombian technical standards (NTC).The standard method of plate count was used for the determination of mesophilic aerobic microorganisms (NTC, 4519) and mould and yeast count (UFC $\left.\mathrm{g}^{-1}\right)$ (NTC, 4092), total coliform count (NTC, 4458) and faecal count (NTC, 1325) using the most probable number technique, PMN (NTC, 1325) was used [12].

\section{G. Sensory evaluation}

An untrained panel of 130 inexperienced panelists of both genders was used to evaluate the acceptability of the products. A hedonic scale of 5 points was used, being 1 = "I dislike it very much" and 5 = "I like it very much", measuring the degree of satisfaction that each sample produces when it is tasted by the panelists, thus determining the acceptability of each formulation.

\section{H. Statistical Analysis}

Results were reported as the mean with their respective standard deviation. For the analysis of the physical and chemical results, a variance analysis (ANOVA) was performed with a $5 \%$ significantlevel ,also a minimum significant differences test (DMS) was used to compare the means using the SPSS software (version 13 for Windows).Two repetitions were performed for each treatment, with each sample being analysed in triplicate.

\section{III.RESULTS AND DISCUSSIONS}

\section{A. Analytical determinations}

Table 2 shows the bromatological analyses of the different treatments, it is observed that between the control sample and the first treatment there were statistically significant differences in protein and $\mathrm{pH}$.The moisture content of $\mathrm{T} 1$ and $\mathrm{T} 2$ varied between $64.98 \%$ and $63.52 \%$ respectively, which did not show significant differences $(\mathrm{p}<0.05)$ in relation to the control sample (T4). For the T3 sample, the moisture content was lower $(62.04 \%)$ as a steady decrease occurred as the percentage of substituting sesame paste for fat was increased.Fat for $\mathrm{T} 2$ and $\mathrm{T} 3$ was 26.56 and $31.24 \%$ respectively, with $\mathrm{T} 2$ treatment having a better performance with a lower percentage; the augment of sesame paste increases protein content in the treatments which show statistically significant differences $(\mathrm{p}<0.05)$ in relation to control.The sample with the highest protein content was $\mathrm{T} 2$ with $18.07 \%$ (see Table 2).

Table 2.Results of bromatological analyses of the different treatments.

\begin{tabular}{|c|c|c|c|c|c|}
\hline Treatments & Moisture (\%) & Ash (\%) & Fat (\%) & Protein (\%) & pH \\
\hline T4(Control) & $64.61 \pm 1.37 \mathrm{a}$ & $2.41 \pm 0.36 \mathrm{a}$ & $33.91 \pm 0.56 \mathrm{a}$ & $12.92 \pm 0.63 \mathrm{c}$ & $6.32 \pm 0.01 \mathrm{~d}$ \\
\hline $\mathrm{T} 1$ & $64.98 \pm 0.49 \mathrm{a}$ & $2.44 \pm 0.10 \mathrm{a}$ & $36.01 \pm 0.72 \mathrm{a}$ & $14.88 \pm 0.30 \mathrm{a}$ & $5.33 \pm 0.01 \mathrm{a}$ \\
\hline $\mathrm{T} 2$ & $63.52 \pm 0.85 \mathrm{ab}$ & $2.78 \pm 0.18 \mathrm{ab}$ & $26.56 \pm 1.00 \mathrm{~b}$ & $18.07 \pm 0.24 \mathrm{~b}$ & $5.44 \pm 0.04 \mathrm{~b}$ \\
\hline $\mathrm{T} 3$ & $62.04 \pm 0.07 \mathrm{~b}$ & $3.10 \pm 0.11 \mathrm{~b}$ & $31.24 \pm 1.28 \mathrm{c}$ & $17.31 \pm 0.44 \mathrm{~b}$ & $5.55 \pm 0.03 \mathrm{c}$ \\
\hline
\end{tabular}

Note:Values with different lettering between the same columns show significant statistical differences at $95 \%$ confidence level.

The reduction in fat content of a meat product decreases emulsifying stability, possibly because fat stabilizes the emulsion by acting as a spacer within the protein network.However, studies carried out by Rodriguez et al., [15] on the use of inulin and bovine plasma as fat substitutes in minced meat, reported that the addition of bovine plasma proteins and inulin in lower fat formulations improved stability compared to the control sample.This behavior was also verified by previous studies, which found that the water retention capacity in plasma protein concentrate was $74 \%$ higher than the fat binding capacity[15]. This could be explained because its high protein content, which forms a denser network of highly aggregated protein (during cooking), could put pressure on fat globules by binding and extracting a fraction of the protein matrix[16].

\section{B. Fatty acids and cholesterol profile}

Table 3 shows the fatty acid and cholesterol profile of the treatments studied, taking into account the percentage of total fat shown in Table 2. It is evident that saturated fatty acids such as palmitic varied from $2.05 \%$ to $0.61 \%$, with T2 treatment being the one that reported the lowest proportion, and myristic acid also obtained a decrease of $35.4 \%$ in relation to control.There is also evidence that oleic acid from the T2 treatment was the one that obtained the best result, being $33 \%$ higher than the control. On the other hand, cholesterol decreased on average by $38.41 \%$ of all treatments compared to the control sample.It is also detailed that myristic, palmitic acid and cholesterol had significant differences in all treatments. Likewise, T1 and T2 treatment had significant differences with the control sample, but T3 treatment showed no differences with respect to control and T1 and T2.On the other hand, the control sample and T3 treatment had significant differences in relation to linoleic acid, but the $\mathrm{T} 1$ and $\mathrm{T} 3$ treatment had no differences with the other treatments. 
Table 3. Fatty acid and cholesterol composition.

\begin{tabular}{|c|c|c|c|c|}
\hline Fatty acid & T4(Control) & T1 & T2 & T3 \\
\hline Butyric & $0.151 \pm 0.001 \mathrm{ab}$ & $0.169 \pm 0.027 \mathrm{ab}$ & $0.195 \pm 0.016 \mathrm{a}$ & $0.137 \pm 0.022 \mathrm{~b}$ \\
\hline Myristic & $0.415 \pm 0.004 \mathrm{a}$ & $0.223 \pm 0.008 \mathrm{~b}$ & $0.187 \pm 0.009 \mathrm{c}$ & $0.147 \pm 0.007 \mathrm{~d}$ \\
\hline Palmitoleic & $3.100 \pm 0.038 \mathrm{ab}$ & $3.188 \pm 0.195 \mathrm{ab}$ & $3.419 \pm 0.387 \mathrm{a}$ & $2.743 \pm 0.387 \mathrm{~b}$ \\
\hline Palmitic & $2.054 \pm 0.9079 \mathrm{a}$ & $1.025 \pm 0.470 \mathrm{~b}$ & $0.610 \pm 0.046 \mathrm{c}$ & $1.731 \pm 0.869 \mathrm{~d}$ \\
\hline Stearic & $0.282 \pm 0.010 \mathrm{a}$ & $0.301 \pm 0.014 \mathrm{a}$ & $0.363 \pm 0.012 \mathrm{~b}$ & $0.339 \pm 0.023 \mathrm{ba}$ \\
\hline Linoleic & $5.837 \pm 0.031 \mathrm{a}$ & $5.78 \pm 0.014 \mathrm{ab}$ & $5.586 \pm 0.137 \mathrm{~b}$ & $5.722 \pm 0.098 \mathrm{ab}$ \\
\hline Oleic & $1.959 \pm 0.052 \mathrm{a}$ & $2.573 \pm 0.262 \mathrm{~b}$ & $2.927 \pm 0.020 \mathrm{~b}$ & $2.499 \pm 0.325 \mathrm{ab}$ \\
\hline Heptadecanoic & $0.134 \pm 0.007 \mathrm{a}$ & $0.128 \pm 0.017 \mathrm{a}$ & $0.072 \pm 0.005 \mathrm{~b}$ & $0.069 \pm 0.007 \mathrm{~b}$ \\
\hline \%-linolenic & $0.088 \pm 0.002 \mathrm{a}$ & $0.110 \pm 0.010 \mathrm{a}$ & $0.136 \pm 0.005 \mathrm{~b}$ & $0.108 \pm 0.013 \mathrm{a}$ \\
\hline$\alpha$-linolenic & $0.151 \pm 0.001 \mathrm{ab}$ & $0.169 \pm 0.027 \mathrm{ab}$ & $0.195 \pm 0.016 \mathrm{a}$ & $0.137 \pm 0.022 \mathrm{~b}$ \\
\hline Cholesterol & $13.015 \pm 0.180 \mathrm{a}$ & $10.615 \pm 0.1804 \mathrm{~b}$ & $8.048 \pm 0.715 \mathrm{c}$ & $5.381 \pm 0.456 \mathrm{~d}$ \\
\hline
\end{tabular}

Note:Values with different letters between the same row show significant statistical differences at $95 \%$ confidence level.

The use of sesame paste as a partial fat substitute improves the lipid profile, also reduces the composition of saturated fatty acids and increases unsaturated fatty acids; several research studies have reported this behavior using other types of substitutes [17].Studies by Choi et al.,[18] reported that they were able to reduce cholesterol by $45-50 \%$ in hamburgers substituted with vegetable oils and rice bran fiber. On the other hand Gök, et al., [14] obtained an $87.97 \%$ reduction in cholesterol by using poppy seed as a fat substitute.

\section{Texture profile analysis (TPA)}

Table 5 shows the textural properties of the analysed treatments, these parameters were influenced by the addition of sesame paste, hardness and fracturability showed a significant increase $(\mathrm{p}<0.05)$ proportional to the addition of the substitute.

Table 4. Texture profile (TPA) of hamburgers.

\begin{tabular}{|c|l|l|l|l|}
\hline Treatments & $\begin{array}{l}\text { Fracturability } \\
\text { (kg m s }^{-2} \text { ) }\end{array}$ & $\begin{array}{l}\text { Springiness } \\
\text { (adimentional) }\end{array}$ & Hardness (Kg) & $\begin{array}{l}\text { Adhesiveness } \\
\text { (Joules) }\end{array}$ \\
\hline T4(Control) & $109.67 \pm 0.44 \mathrm{~d}$ & $0.797 \pm 0.0011^{\mathrm{a}}$ & $107.508 \pm 2.18 \mathrm{~d}$ & $-1.4641 \pm 0.07 \mathrm{a}$ \\
\hline $\mathrm{T} 1$ & $149.47 \pm 2.88 \mathrm{a}$ & $0.794 \pm 0.0038^{\mathrm{a}}$ & $146.532 \pm 1.13 \mathrm{a}$ & $-1.3375 \pm 0.05 \mathrm{a}$ \\
\hline $\mathrm{T} 2$ & $197.31 \pm 0.88 \mathrm{~b}$ & $0.801 \pm 0.0007 \mathrm{~b}$ & $195.787 \pm 0.53 \mathrm{~b}$ & $-1.6291 \pm 0.02 \mathrm{a}$ \\
\hline $\mathrm{T} 3$ & $216.75 \pm 0.11 \mathrm{c}$ & $0.795 \pm 0.0028^{\mathrm{a}}$ & $213.425 \pm 0.40 \mathrm{c}$ & $-2.6375 \pm 0.36 \mathrm{~b}$ \\
\hline
\end{tabular}

Note: Values with different lettering between the same columns show significant statistical differences at $95 \%$ confidence level.

All textural parameters tended to decrease as $\mathrm{pH}$ decreased, indicating that protein-protein bonds were affected by developing weaker gels. The hardness of plasma gels was significantly affected by $\mathrm{pH}$ [19]. For the other hand, Julio et al., [11] evaluated the quality and acceptability of chorizos formulated with blood plasma and sesame paste, reporting that the products made with plasma and sesame paste resulted in higher yields, and the lower fat values were presented by the formulation with higher plasma and paste content. The use of fat substitutes in meat products, in addition to reducing fat content, modifies texture, including proteins and carbohydrates. Several investigations have confirmed this fact, according to Summo et al. [20] the factors responsible for the textural properties in crushed meats are the degree of extraction of myofibrillary proteins, the protein content, the degree of crushing of meat and the types and levels of non-meat ingredients.

\section{Physical properties}

Table 5 shows the physical properties of the treatments studied. There is evidence that $\mathrm{T} 1$ and $\mathrm{T} 2$ treatment had no significant differences in cooking yield, but if differences were observed with the control sample in this property, then $\mathrm{T} 3$ treatment did not report differences with the other samples. It was also observed that in fat retention in T1 and T3 treatment they had no statistical differences, but were significant with the T2 sample and control. With regard to moisture retention between the T1 and T2 samples, statistically significant differences were observed, although the control sample did not differ from the other treatments. 
Table 5. Physical properties of the different treatments

\begin{tabular}{|c|c|c|c|}
\hline Treatments & Cooking yield & Fat retention & Moisture retention \\
\hline T4(Control) & $83.24 \pm 0.86 \mathrm{~b}$ & $75.94 \pm 0.81 \mathrm{c}$ & $51.31 \pm 0.54 \mathrm{ab}$ \\
\hline $\mathrm{T} 1$ & $88.31 \pm 0.01 \mathrm{a}$ & $71.22 \pm 0.11^{\mathrm{a}}$ & $46.68 \pm 1.29 \mathrm{a}$ \\
\hline $\mathrm{T} 2$ & $87.41 \pm 2.31 \mathrm{a}$ & $89.27 \pm 1.21 \mathrm{~b}$ & $50.41 \pm 1.34 \mathrm{~b}$ \\
\hline $\mathrm{T} 3$ & $85.20 \pm 0.96 \mathrm{ab}$ & $72.43 \pm 2.10^{\mathrm{a}}$ & $47.69 \pm 0.47 \mathrm{a}$ \\
\hline
\end{tabular}

Note: Values with different lettering between the same columns show significant statistical differences at $95 \%$ confidence level.

The ability to retain moisture and other juices in the product before and after treatment is an important attribute of sausages and other meat emulsions. The stability of the emulsion, which measures how well the juices are retained, is an effective parameter that influences the shelf life of the product [10]. Cooking loss measures the system's ability to retain water and fat after denaturation and protein aggregation during cooking [21]. The probable reason for this is probably the higher starch content in cornmeal, which allowed the matrix of the meat emulsion to retain more water. Choi et al., [19] reported that the addition of rice fibre in meat products improves emulsion stability. Research by Marchetti et al., [22] reported that low-lipid meat emulsions formulated with protein (milk protein concentrate, whey protein concentrate) showed greater stability than control, indicating improved stability and water retention capacity in the emulsion. Studies by Zhuang et al., [3] explain that the addition of sesamol, which is a lipid-soluble polyphenol, provides a hygroscopic effect that reduces moisture loss from muscle fibers by maintaining the integrity of the fiber membrane and therefore increased the water retention capacity of pork sausages. These authors reported that the addition of lutein, sesamol, ellagic acid and olive leaf extract had no significant effect on loss of cooking relative to control of pork sausages.

\section{E. Microbiological analysis}

Table 6 shows the microbiological analyses carried out on hamburger meat, in which it is observed that the results are within the limits of standard NTC 1325 [12] by the addition of sesame paste, these showed concentrations of microorganisms lower than those allowed in the Colombian Technical Standard NTC 1325. Also Isaza et al., [23] reported mesophilic aerobic values of $40 \mathrm{CFU} \mathrm{g}^{-1}$ with $10 \%$ commercial bovine plasma in sausage type sausage, total coliform NMP and fungi and yeast respectively. Benítez et al. [24] reported values of 4.02 for mesophilic aerobics, total coliforms and fungi and yeast within the boundary, these authors explain that the high probability of contamination of liquid plasma which provides a favourable method for microorganism growth.

Table 6. Microbiological analysis of the treatments

\begin{tabular}{|c|c|c|c|}
\hline Treatments & 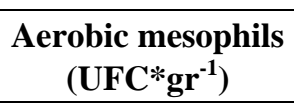 & $\begin{array}{c}\text { Mushrooms and yeast } \\
\left(\mathrm{UFC}^{*} \mathrm{gr}^{-1}\right)\end{array}$ & $\begin{array}{c}\text { Total coliforms } \\
\left(\text { Organisms* } \text { gr }^{-1}\right)\end{array}$ \\
\hline $\mathrm{T} 1$ & $<10$ & $<10$ & $<3$ \\
\hline $\mathrm{T} 2$ & $<10$ & $<10$ & $<3$ \\
\hline T3 & $<10$ & $<10$ & $<3$ \\
\hline
\end{tabular}

\section{F. Sensory evaluation}

Figure 1 depicts the effects of adding sesame paste on the sensory parameters studied. It is observed that the T2 treatment showed better grades for colour, texture and flavour. Sansawat et al., [1] reported that the addition of plum puree did not significantly affect the sensory parameters of hamburger meat. Researches conducted by Viana et al., [25] evaluated the quality of ham with bovine plasma as a fat substitute, these authors reported that no difference was observed in the three plasma formulations compared to control, however colour was reduced with all samples, this can be explained because fat influences the colour of meat products. 


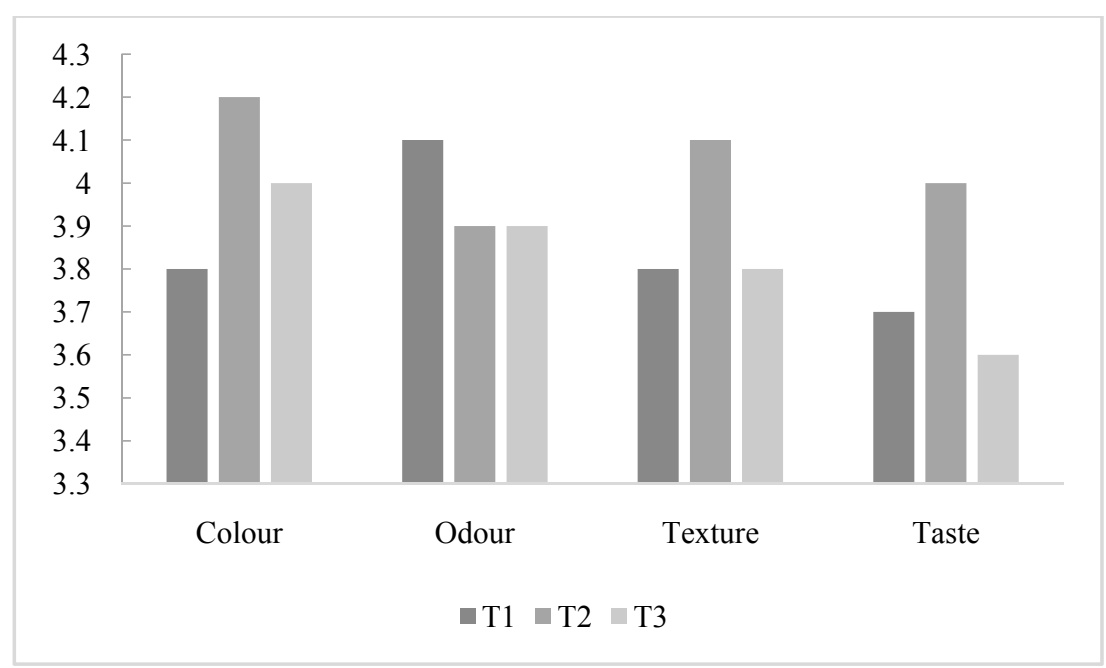

Fig. 1. Sensory evaluation of hamburguers.

\section{IV.CONCLUSIONS}

The use of sesame paste as a partial fat substitute improved the lipid profile by reducing the composition of saturated fatty acids and increasing unsaturated fatty acids, and also gradually lowered the cholesterol content of the product. It was also observed that the textural parameters decreased as $\mathrm{pH}$ decreased, however hardness and fracturability increased. The T2 treatment presented the best behavior in terms of physical, chemical and sensory properties, so it is concluded that adding more than $50 \%$ of this substitute significantly affects the nutritional quality of the final product. Sesame paste can be considered a fat substitute because it generates an excellent technological and functional response in hamburger meat.

\section{ACKNOWLEDGMENT}

The authors are grateful to COLCIENCIAS for the financing of project 110766441920 in the Convocatoria 664 of 2014.

\section{REFERENCES}

[1] T. Sansawat, H. C. Lee, P. Singh, N. Hall, and K. Iksoon, "Quality and sensory characteristics of low-fat hamburger patty prepared with wheat-based protein (WP)," Meat Sci., vol. 101, pp. 118-119, Mar. 2015.

[2] M. Al-Bachir, "Some microbial, chemical and sensorial properties of gamma irradiated sesame (Sesamum indicum L.) seeds," Food Chem., vol. 197, pp. 191-197, Apr. 2016.

[3] X. Zhuang et al., "Effects of the sugarcane dietary fiber and pre-emulsified sesame oil on low-fat meat batter physicochemical property, texture, and microstructure," Meat Sci., vol. 113, pp. 107-115, Mar. 2016.

[4] D. Peng, Y. Bi, X. Ren, G. Yang, S. Sun, and X. Wang, "Detection and quantification of adulteration of sesame oils with vegetable oils using gas chromatography and multivariate data analysis," Food Chem., vol. 188, pp. 415-421, Dec. 2015.

[5] I. Benet, M. D. Guàrdia, C. Ibañez, J. Solà, J. Arnau, and E. Roura, "Low intramuscular fat (but high in PUFA) content in cooked cured pork ham decreased Maillard reaction volatiles and pleasing aroma attributes," Food Chem., vol. 196, pp. 76-82, Apr. 2016.

[6] H. Yang et al., "Effect of protein structure on water and fat distribution during meat gelling," Food Chem., vol. 204, pp. 239-245, Aug. 2016.

[7] I. M. Chernukha, L. V. Fedulova, and E. A. Kotenkova, "Meat by-product is a Source of Tissue-specific Bioactive Proteins and Peptides against Cardio-vascular Diseases," Procedia Food Sci., vol. 5, pp. 50-53, 2015.

[8] M. M. Selani et al., "Effects of pineapple byproduct and canola oil as fat replacers on physicochemical and sensory qualities of low-fat beef burger," Meat Sci., vol. 112, pp. 69-76, Feb. 2016.

[9] $\mathrm{H}$. Wu et al., "Influence of partial replacement of $\mathrm{NaCl}$ with $\mathrm{KCl}$ on profiles of volatile compounds in dry-cured bacon during processing," Food Chem., vol. 172, pp. 391-399, Apr. 2015.

[10] M. Tahmasebi, M. Labbafi, Z. Emam-Djomeh, and M. S. Yarmand, "Manufacturing the novel sausages with reduced quantity of meat and fat: The product development, formulation optimization, emulsion stability and textural characterization," LWT - Food Sci. Technol., vol. 68, pp. 76-84, May 2016.

[11] L. C. Julio, P. M. Montero, and D. Acevedo, "Calidad y Aceptabilidad de Chorizos Formulados con Plasma Sanguíneo Bovino y Pasta de Ajonjolí,” Inf. tecnológica, vol. 26, no. 3, pp. 25-32, 2015.

[12] Instituto Colombiano de Normas Técnicas y de Certificación (ICONTEC), NTC 1325. Industrias alimentarias, Productos cárnicos procesados no enlatados. 2005.

[13] AOAC, Official methods of analysis of AOAC International. AOAC International., 18th ed. 2005.

[14] V. Gök, L. Akkaya, E. Obuz, and S. Bulut, "Effect of ground poppy seed as a fat replacer on meat burgers," Meat Sci., vol. 89, no. 4, pp. 400-404, Dec. 2011.

[15] J. G. Rodríguez-Carpena, D. Morcuende, and M. Estévez, "Avocado, sunflower and olive oils as replacers of pork back-fat in burger patties: Effect on lipid composition, oxidative stability and quality traits," Meat Sci., vol. 90, no. 1, pp. 106-115, Jan. 2012.

[16] K. J. Phelps et al., "Effect of the Programmed Nutrition Beef Program on moisture retention of cooked ground beef patties and enhanced strip loins," Meat Sci., vol. 100, pp. 189-194, Feb. 2015.

[17] H. Yang et al., "Changes in protein structures to improve the rheology and texture of reduced-fat sausages using high pressure processing," Meat Sci., vol. 121, pp. 79-87, Nov. 2016.

[18] Y.-S. Choi et al., "Characteristics of low-fat meat emulsion systems with pork fat replaced by vegetable oils and rice bran fiber," Meat Sci., vol. 82, no. 2, pp. 266-271, Jun. 2009. 
[19] E. Dàvila, D. Parés, G. Cuvelier, and P. Relkin, "Heat-induced gelation of porcine blood plasma proteins as affected by pH," Meat Sci., vol. 76, no. 2, pp. 216-225, Jun. 2007.

[20] C. Summo, I. Centomani, V. M. Paradiso, F. Caponio, and A. Pasqualone, "The effects of the type of cereal on the chemical and textural properties and on the consumer acceptance of pre-cooked, legume-based burgers," LWT - Food Sci. Technol., vol. 65, pp. 290-296, Jan. 2016.

[21] G. Y. Turp, "Effects of four different cooking methods on some quality characteristics of low fat Inegol meatball enriched with flaxseed flour," Meat Sci., vol. 121, pp. 40-46, Nov. 2016.

[22] L. Marchetti, S. C. Andrés, and A. N. Califano, "Textural and thermal properties of low-lipid meat emulsions formulated with fish oil and different binders," LWT - Food Sci. Technol., vol. 51, no. 2, pp. 514-523, May 2013.

[23] J. M. Isaza Rengifo, L. Londoño Ramírez, D. Restrepo Molina, M. Cortes Rodriguez, and H. Suárez Mahecha, "Producción y propiedades funcionales de plasma bovino hidratado en embutido tipo salchichón,” Rev. Colomb. Ciencias Pecu., vol. 11, no. 7, pp. 199-206, 2010.

[24] B. M. Benítez P, E. Márquez S, Y. Barboza, P. Izquierdo, and B. A. De Muñoz, "Formulación y características de productos cárnicos elaborados con subproductos de la industria animal," Rev. Cient. la Fac. Ciencias Vet. la Univ. del Zulia, vol. 10, no. 4, pp. 321-327, 2000.

[25] F. R. Viana, V. D. M. Silva, F. M. Delvivo, C. S. Bizzotto, and M. P. C. Silvestre, "Quality of ham pâté containing bovine globin and plasma as fat replacers," Meat Sci., vol. 70, no. 1, pp. 153-160, May 2005.

\section{AUTHOR PROFILE}

Piedad Margarita Montero-Castillo works as a full-time professor at the Universidad de Cartagena. Dr. Montero-Castillohas adoctoral degree in Sciences from the Universidad Rafael BellosoChacín (Venezuela). She also has a master degree in Food Science and Technology and a bachelor degree in Food Engineering from the Universidad del Zulia (Venezuela) and the Universidad de la Salle (Colombia), respectively. She is director of the Research Group NUSCA.

Erica P. Torres-Julio works as research assistant in the Research Group NUSCA and has a bachelor degree in Food Engineering from the Universidad de Cartagena.

Dayana P. Pérez-Rodríguez works as research assistant in the Research Group NUSCA and has a bachelor degree in Food Engineering from the Universidad de Cartagena. 